EUROPEAN CENTRAL BANK

WORKING PAPER SERIES

N0. 347 / APRIL 2004

\title{
FIRMS' \\ INVESTMENT \\ DECISIONS IN \\ RESPONSE TO \\ DEMAND AND PRICE UNCERTAINTY
}

by Catherine Fuss

and Philip Vermeulen

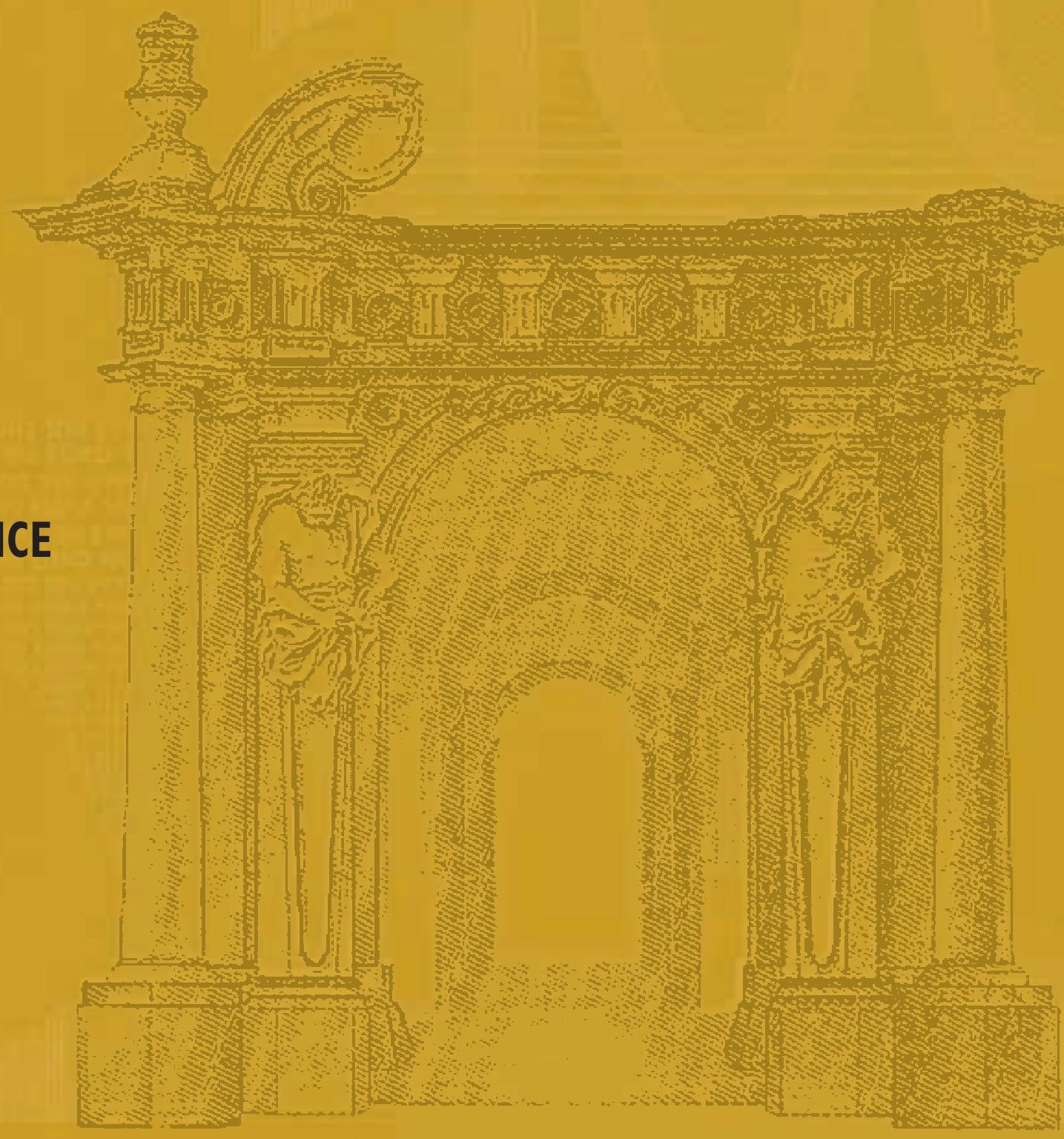




\title{
WORKING PAPER SERIES
}

N0. 347 / APRIL 2004

\author{
FIRMS' \\ INVESTMENT \\ DECISIONS IN \\ RESPONSE TO \\ DEMAND AND PRICE \\ UNCERTAINTY
}

by Catherine Fuss ${ }^{2}$

and Philip Vermeulen ${ }^{3}$

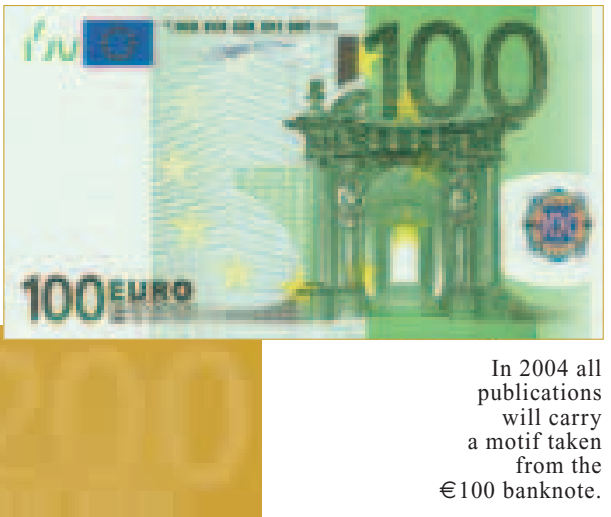

This paper can be downloaded without charge from http://www.ecb.int or from the Social Science Research Network electronic library at http://ssrn.com/abstract_id $=532990$.

I We would like to thank Paul Butzen, Patrick Sevestre, Anders Warne, Rafael Wouters and participants at the seminar at the Université Libre de Bruxelles for useful discussions. We would also like to express our gratitude to an anonymous referee for useful suggestions. Many thanks are owed as well to Frank Windmeijer for providing us with the codes for the Windmeijer correction in dynamic panels. The opinions expressed in this paper are solely our own and do not necessarily reflect the opinion of the National Bank of Belgium or the European Central Bank. 


\section{드 European Central Bank, 2004}

\section{Address}

Kaiserstrasse 29

60311 Frankfurt am Main, Germany

Postal address

Postfach 160319

60066 Frankfurt am Main, Germany

Telephone

+496913440

\section{Internet}

http://www.ecb.int

Fax

+496913446000

Telex

411144 ecb d

All rights reserved.

Reproduction for educational and noncommercial purposes is permitted provided that the source is acknowledged.

The views expressed in this paper do not necessarily reflect those of the European Central Bank.

The statement of purpose for the ECB Working Paper Series is available from the ECB website, http://www.ecb.int.

ISSN 1561-0810 (print)

ISSN 1725-2806 (online) 


\section{CONTENTS}

Abstract 4

Non-technical summary 5

I. Introduction 6

II. Related literature 8

III. Measuring uncertainty I0

IV. The data set I/3

V. The empirical framework $\quad$ |4

VI. Empirical results $\quad$ | 6

VII. Conclusions 2 2 I

Appendix $\quad 22$

References 25

European Central Bank working paper series 28 


\begin{abstract}
We estimate the effect of demand and price uncertainty on firms' investment decisions from a panel of manufacturing firms. Uncertainty measures are derived from firms' subjective qualitative expectations. They are close to their theoretical counterparts, the variances of future demand and price shocks. We find that demand uncertainty depresses planned and realized investment, while price uncertainty is insignificant. This is consistent with the behavior of monopolistic firms with irreversible capital (Caballero, 1991). Further, firms revise their investment plans very little. They may do so in response to new information on sales growth, but not as a result of reduced uncertainty.
\end{abstract}

Keywords: investment, uncertainty, real options, survey data, panel data

JEL Classification: D21, D24, D81, D92, C23 


\section{Non technical summary}

It has often been argued that stabilizing the economic environment would stimulate private investment and growth. In this paper we assess the impact of demand and price uncertainty on the level of investment and on investment revisions of manufacturing firms. Theoretically speaking, uncertainty may affect not only the level of investment but also the timing of investment. The following predictions may be deduced from the theory. For perfectly competitive firms, an increase in either price or demand uncertainty would raise the level of investment. For imperfectly competitive firms whose capital is irreversible, higher demand uncertainty leads to lower investment. Finally, firms that make use of irreversible capital and have some flexibility in the timing of their investment, prefer to adopt a "wait and see" approach and delay investment when uncertainty augments. Indeed, waiting allows the firm to gather new information on the uncertain future. A testable implication of the latter prediction is that firms may revise their investment decisions when they acquire new information on their fundamentals (e.g. sales growth) or if the level of uncertainty changes at the time the investment is realized.

We construct measures of demand and price uncertainty that are relatively close to their theoretical counterparts, thanks to a survey in which firms report their own subjective expectations of future demand and output price changes. Furthermore, using an investment survey that contains quantitative information on planned and realized investment, we examine the effect of uncertainty on investment from three viewpoints. First, we consider the impact of uncertainty on the ex-ante investment decisions (investment plans). Second, we compare this to the ex-post investment realizations, which will ultimately affect the business cycle and growth. Third, by comparing the difference between planned and realized investment, we analyze the effect of uncertainty and new information concerning the firms' fundamentals on investment revisions. This is an indirect test of the effect of uncertainty on the timing of investment.

Our results show that demand uncertainty has a negative effect on investment plans and realized investment. These results confirm the prediction of the literature on uncertainty for imperfectly competitive firms. We find no effect of price uncertainty. We argue that our measure of price uncertainty is ill-suited for imperfectly competitive firms, because future price changes may be known rather than uncertain for price-setting firms. Finally, our estimates suggest that firms possibly gear their investment decisions to new information on sales growth, but do not modify their investment plans due to changes in uncertainty.

All in all, our results indicate that reducing the level of demand uncertainty would enhance planned and realized investment, but that plans are not revised as a result of a change in uncertainty. This suggests that a reduction in the level of uncertainty would only have lagged effects on investment, since uncertainty affects investment plans but not revisions of currently realized investment. 


\section{Introduction}

A large body of literature has investigated the effect of uncertainty on investment. The theoretical implications of uncertainty on investment are twofold. First, uncertainty may affect the level of investment. Second, uncertainty may affect the timing of investment. Although it is uncontroversial that uncertainty may theoretically affect investment, there is no conclusive agreement on the sign of the investment-uncertainty relationship. In this paper we empirically assess the effect of demand and price uncertainty on firm's investment decisions. We not only assess the impact of uncertainty on the level of investment, but also analyze its effect on the timing of investment decisions.

We construct measures of demand and price uncertainty that are relatively close to their theoretical counterparts and capture the investment decision process at the firm level. To measure uncertainty, we rely on a survey in which firms report their own subjective expectations of future demand and output price changes. This allows us to avoid measurement problems often encountered in the literature. As to investment decisions, we use an investment survey that contains information on planned and realized investment of manufacturing firms. Combining the two surveys, we examine the effect of demand and price uncertainty on the level of investment. We consider both the ex ante investment decisions (investment plans) and the ex post investment realizations. Next, by comparing the difference between planned and realized investment, we analyze the effect of uncertainty on the timing of investment. By looking at both the level and timing effects and by considering both demand and price uncertainty this paper provides empirical tests of three theories: the theory of firm investment under price uncertainty, the theory of firm investment under demand uncertainty and the real-options theory of investment.

The implications of demand and price uncertainty for the level of firm investment have been derived by Hartman (1972), Abel (1983) and Caballero (1991), among others. Hartman (1972) and Abel (1983) show that output price uncertainty increases investment of a risk-neutral firm operating in perfect competition with constant returns to scale production function and no irreversibility. Within such a setting, the marginal profitability of capital is convex to prices, so that Jensen's inequality applies. ${ }^{1}$ Caballero (1991) shows that this result solely depends on the assumption of perfect competition and constant returns to scale. He finds that the investmentuncertainty relationship remains positive for perfectly competitive firms even if the capital stock is irreversible. Imperfect competition (or decreasing returns to scale) ${ }^{2}$ dampens the positive effect of demand uncertainty on investment. ${ }^{3}$ If, in addition, the capital stock is irreversible, i.e. if capital

1 An increase in demand uncertainty increases the probability of both positive and negative demand shocks. However, by convexity of the marginal profitability of capital, increases in profitability due to positive demand shocks are larger than reductions in profitability due to negative demand shocks.

2 Imperfect competition and decreasing returns to scale play a symmetrical role in Caballero (1991) 's model.

3 This can be attributed to the following fact. With a flat demand curve, the perfectly competitive firm can benefit from both price and output increases, in response to a positive demand shock. With an elastic demand curve, the imperfectly competitive firm can increase output only at the cost of lower prices. Therefore, the profit derived from a positive demand shock is lower. 
cannot be resold or only at a lower price than the purchase price, the sign of the investmentuncertainty relationship may turn negative. Indeed, when the capital stock cannot be resold free of charges, the firm prefers to have insufficient capacity rather than excess capital stock. Since increased uncertainty raises the probability of excess capital stock, the firm will invest less today to reduce the probability of excess capacity tomorrow. ${ }^{4}$

In conclusion, the direction of the investment-demand uncertainty relationship depends on the combination of the slope of the demand curve, the asymmetry of adjustment costs (i.e. the degree of irreversibility) and the degree of returns to scale. ${ }^{5}$ More market power, more decreasing returns to scale, and more irreversibility all make it more likely that the investment-demand uncertainty relationship is negative. So, under imperfect competition (or decreasing returns to scale), more demand uncertainty may reduce investment. On the contrary, under perfect competition, increased price uncertainty should enhance current investment. Since we have no prior information on whether firms in our sample operate in rather imperfect or in close to perfectly competitive markets, we test both demand and price uncertainty on the same firms. In doing so, we examine the predictions made in Hartman (1972) and Abel (1983) for perfectly competitive firms, and in Caballero (1991) for imperfectly competitive firms. We predict that, if firms of our sample are perfectly competitive, our measure of price uncertainty will affect investment positively, whereas, if they are imperfectly competitive, the measure is likely to be insignificant, and demand uncertainty is likely to reduce investment.

The effect of uncertainty on the timing of investment is investigated in the real-options theory. Using the theory of options, McDonald and Siegel (1986), Dixit and Pindyck (1994) and Abel and Eberly (1994), among others, show that, when investment is irreversible and there is some flexibility in the timing of investment, there is a positive-value option to wait. In fact, by waiting, the firm incurs a loss of current profits but acquires more information about the uncertain future; hence, waiting (partly) dissolves uncertainty. Uncertainty increases the value of the waiting option thereby making it more optimal to postpone investment. Abel et al (1996) consider the more general case with additional costs of waiting and the capital stock not necessarily being fully irreversible. In their model, on the one hand, the firm has an option to wait (expandability option), but this may be costly when future investment prices are higher than current investment prices. On the other hand, when the capital stock may be resold, even though the resale price may be lower than the purchase price, the firm has a reversibility option. Increased uncertainty (about future returns) increases the value of both the expandability and the reversibility options, so that the ultimate effect on investment is ambiguous. But the effect turns negative, as investment is more irreversible. In sum, increased uncertainty tends to delay investment when the capital stock is more

Note that this effect may even be negative if the marginal profitability of capital is concave rather than convex in the demand shock (see footnote 6 on page 280 of Caballero, 1991)

4 For perfectly competitive firms the marginal profitability of capital does not depend on previous investment so that irreversibility does not affect the sign of the investment-uncertainty relationship.

5 We do not consider risk aversion in the discussion and rather assume that firms are risk-neutral. 
irreversible. In this paper, we investigate the effect of new information on investment revisions, defined as the difference between realized and planned investment. In this way, we analyze the predictions of the real-option theory, according to which firms have a positive-value option to wait in order to gather more information about the uncertain future, thereby reducing uncertainty. We test whether firms modify their investment plans in view of new information on their fundamentals or due to partly dissolved uncertainty.

This paper is an extension of our previous analysis (Butzen et al, 2003). Here, we analyze both planned and realized investment, and we examine the determinants of investment revisions. ${ }^{6}$ Our results show that demand uncertainty has a negative effect on investment plans and realized investment. These results confirm the prediction of the literature on uncertainty for imperfectly competitive firms (as in Caballero, 1991). We find no effect of price uncertainty. We argue that our measure of price uncertainty is ill-suited for imperfectly competitive firms, because future price changes may be known rather than uncertain for price-setting firms. In addition, we find that, on average, firms carry out little revisions of their investment plans, although there are substantial variations across firms. Our estimates suggest that firms possibly adjust their investment decisions to new information about sales growth, but do not modify their investment plans due to changes in uncertainty.

The rest of the paper is structured as follows. In section II we describe the related literature. Section III discusses our measures of uncertainty. In section IV we present the data. In Section V we develop the empirical framework. Section VI contains our empirical results. We first evaluate the effect of uncertainty on investment plans and investment decisions. Next, we investigate the differences in the plans and realizations behavior. Finally, we test whether firms revise their investment decisions in response to new information about fundamentals or reductions in uncertainty, as predicted by the real-option theory. Section VII concludes.

\section{Related literature}

The literature on the relationship between uncertainty and investment is relatively extensive. A recent detailed survey is provided by Carruth et al (2000). In this paper we focus on the effect of firm-specific uncertainty on firm 's investment. Three types of firm-level uncertainty are recurrent in the literature. First, the relationship between investment and output price uncertainty for the perfectly competitive firm is developed in Hartman (1972), Abel (1983) and Abel and Eberly (1997). They focus on uncertainty about future output price changes, which is formally defined as its variance. Second, the effect of demand uncertainty on investment for the imperfectly competitive firm is analyzed in Caballero (1991). He defines uncertainty as the variance of a shock

6 Also, we use other estimation techniques, and, by focusing on a sample of firms for which more information is available, we define firms' fundamentals more precisely. Therefore, this paper may be seen as a robustness check of our previous results. 
to the demand curve. Third, the consequences of profit uncertainty for investment are investigated in Abel and Eberly (1994). Uncertainty in this model is defined as the variance of a shock to the profit function. The advantage of this modelling approach is that the shock to the profit function incorporates all possible shocks stemming from both demand and supply side factors: i.e. changes in tastes, technology, output prices and input prices.

Most of the empirical literature uses aggregate investment data to analyze the relationship between investment and uncertainty. For example, using industry data, Ghosal and Loungani (2000) measure profit uncertainty by the standard deviation of the residuals of a profit-forecasting equation at the industry level and hence are close to the theoretical uncertainty measure. They find that profit uncertainty reduces industry investment. Ghosal and Loungani (1996) and Henley et al (2003) test the effect of output price uncertainty on investment at the industry level. They find a negative impact of price uncertainty on investment. The magnitude of the effect may depend on the degree of competition. For Ghosal and Loungani (1996) it is significant only in competitive industries. For Henley et al (2003), the effect is more significant in concentrated industries.

In contrast to these papers, we focus on individual investment by firms. We only know of a few other papers that investigate the relationship between firm's investment and firm-specific uncertainty. Most of these papers however use measures of uncertainty that are difficult to interpret in light of the theory. In a seminal paper, Leahy and Whited (1996) use a forecast of the variance of the daily stock return as their measure of uncertainty. They find that it negatively affects investment. Although they argue that stock return volatility captures all forms of uncertainty that are relevant for the firm 's investor, it remains that their measure has no direct theoretical counterpart. In addition, stock returns are quite noisy. In the same spirit, Bulan (2000) measures total firm uncertainty as the realized volatility of the firm's equity returns. She finds that uncertainty reduces investment. Bloom et al. (2003) also use the variance of stock returns to measure uncertainty and again find that uncertainty depresses investment.

A few papers use the volatility of unpredictable sales shocks to construct measures of output uncertainty. Von Kalckreuth (2003) uses the variance of the errors of a sales forecasting equation. Bo (2002) relies on forecast errors of sales derived from a state space model. They both find that output uncertainty negatively affects investment. However, sales uncertainty measures are difficult to interpret. Since sales changes are the result of both demand and supply shocks, sales volatility is caused both by demand uncertainty and the volatility of supply shocks. ${ }^{7}$ As such, sales volatility is

7 To illustrate this, consider the following simplified demand and supply functions for a single firm (1) $P_{d}=C_{d} \cdot e^{\varepsilon d} \cdot Q^{\psi}$ with $\psi \leq 0$ ( $\psi=0$ for a perfectly competitive firm), and (2) $P_{s}=C_{s} \cdot e^{\varepsilon s} \cdot Q^{\varphi}$ with $\varphi>0$, where $\varepsilon d$ and $\varepsilon s$ are, respectively, demand and supply shocks independent of each other and with respective variances $\sigma_{\mathrm{d}}$ and $\sigma_{\mathrm{s}}$. From the equilibrium condition on the goods market it may easily be shown that the variances for (the log of) output, $q$, and prices, $p$, depend on the variance of both demand and supply shocks:

$\operatorname{var}[\mathrm{q}]=\sigma_{\mathrm{q}}=\left(\frac{1}{\varphi-\psi}\right)^{2}\left(\sigma_{\mathrm{d}}+\sigma_{\mathrm{s}}\right)$ and $\operatorname{var}[\mathrm{p}]=\sigma_{\mathrm{p}}=\left(\frac{1}{\varphi-\psi}\right)^{2}\left(\varphi^{2} \cdot \sigma_{\mathrm{d}}+\psi^{2} \cdot \sigma_{\mathrm{s}}\right)$ 
not directly related to any theoretical counterpart. In contrast to these papers, we use a measure of demand uncertainty rather than a measure of output volatility.

In all the papers mentioned above, the uncertainty measures are based on observable variables. At best, forward-looking measures are obtained from forecasting equations. By doing so, the econometrician implicitly assumes that all firms produce their forecasts according to this particular forecasting model. Only a small number of papers have used survey data to measure directly firms' perceived uncertainty. Guiso and Parigi (1999) and Patillo (1998) use surveys in which the respondents provide their subjective probability distribution of their own demand changes. Thus, they are able to construct firm-specific measures of future demand growth variance. This measure is clearly the closest to the variance of the shock to the demand curve as in Caballero (1991). Guiso and Parigi (1999) find that increased demand uncertainty reduces investment, and more so for firms with more market power and a more irreversible capital stock. For Ghanaian firms, Patillo (1998) finds that uncertainty raises the trigger value at which firms invest. Temple et al (2001) use a survey in which firms must report whether demand uncertainty limits their capital expenditure, but they do not construct a measure of uncertainty. As in our paper, Driver et al (2002) rely on a survey in which firms convey their qualitative expectations about future developments to construct a measure of uncertainty. In an industry-level analysis, they find that uncertainty about future business conditions depress investment authorizations.

\section{Measuring uncertainty}

We use the monthly Belgian Business Cycle survey to construct our measures of uncertainty. This survey provides firms' expectations about their own future demand and price changes, on the basis of which we construct demand and price uncertainty measures. It reports qualitative information on firms' own subjective expectations about future demand and prices changes. Our measure of demand uncertainty is based on the answers to the following question: ${ }^{8}$

Do you expect demand for your product, in the next three months $(A)$ to rise, $(B)$ to remain unchanged, $(C)$ to decrease, with respect to its average level at that time of the year?

The question directly asks for demand, not output. We assume that the person answering that question therefore presumably thinks first about external factors that can affect the firm's demand, i.e. shocks that shift the demand curve. It seems less plausible that the person thinks of the firm's supply function, hence of input prices, labor costs, technology shocks, taxation, etc.

8 A difficulty of using this information is that the Business Survey reports information by firms' product and plant rather than by firm. Since the information is qualitative we cannot simply add the information for each product. We select the product that accounts for most of the firm 's turnover to approximate the firm 's total demand. 
The answers to the question above capture the firm's own subjective expectation of the value of a future demand shock. These answers are qualitative and are used to construct a measure of demand uncertainty. This approximates the variance of demand shocks on the following assumptions. Assume each firm $i$ from industry $j$ at time $t+1$ will receive a demand shock $d_{i j t+1}=M_{i j t+1}+I_{i j t+1}$, whereby the demand shock can be written as the sum of a random variable $\mathrm{M}_{\mathrm{ijt+1}}$ that distributes good and bad outcomes across firms within industry $j$, and $I_{i j t+1}$ is a firm idiosyncratic shock, orthogonal to $\mathrm{M}_{\mathrm{ijt}+1}$ with mean zero. $\mathrm{M}_{\mathrm{jt+1}}$, can take three values: $+m_{j t+1}, 0,-m_{j t+1}$ with respective probabilities $\mathrm{p}_{\mathrm{jt}+1}(+), \mathrm{p}_{\mathrm{jt}+1}(0)$ and $\mathrm{p}_{\mathrm{jt+1}}(-)$. In other words, a fraction $\mathrm{p}_{\mathrm{jt}+1}(+)$ of the firms will receive a good outcome, a fraction $\mathrm{p}_{\mathrm{jt}+1}(-)$ of the firms will receive a bad outcome. The variance of the demand shocks firms face each period is equal to $\operatorname{var}\left(\mathrm{d}_{\mathrm{ijt}+1}\right)=m_{j t+1}{ }^{2} \cdot\left[\mathrm{p}_{\mathrm{jt}+1}(+)+\mathrm{p}_{\mathrm{jt+1}}(-)-\left(\mathrm{p}_{\mathrm{jt+1}}(+)-\right.\right.$ $\left.\left.\mathrm{p}_{\mathrm{jt+1}}(-)\right)^{2}\right]+\operatorname{var}\left(\mathrm{I}_{\mathrm{jjt}+1}\right)$.

Assume now that at time $\mathrm{t}$ (the time at which the firms answer the questionnaire) each firm observes a signal $S_{\mathrm{ijt}}$ that can take on three values, say $1,0,-1$, and that is perfectly correlated with the shock $\mathrm{M}_{\mathrm{ijt}+1}$. Firms use this signal to form rational expectations about the mean value of their future demand shock and to answer the question of the Business Survey above. Firms receiving the signal 1 can rationally expect a positive shock and expect demand to rise and therefore answer (A), firms receiving the signal -1 rationally expect a negative shock and therefore answer $(C)$. The variance of the signal is equal to $\operatorname{var}\left(\mathrm{S}_{\mathrm{ijt}}\right)=\left[\mathrm{p}_{\mathrm{jt}}(+)+\mathrm{p}_{\mathrm{jt}}(-)-\left(\mathrm{p}_{\mathrm{jt}}(+)-\mathrm{p}_{\mathrm{jt}}(-)\right)^{2}\right]$. Because the signal $\mathrm{S}_{\mathrm{ijt}}$ is perfectly correlated with $\mathrm{M}_{\mathrm{ijt}+1}$, there will be a fraction $\mathrm{p}_{\mathrm{jt}}(+)=\mathrm{p}_{\mathrm{ijt} t 1}(+)$ of the firms expecting a positive demand shock and a fraction $\mathrm{p}_{\mathrm{jt}}(-)=\mathrm{p}_{\mathrm{ijt}+1}(-)$ of the firms expecting a negative demand shock. Therefore the variance of the signal is also equal to $\left[\mathrm{p}_{\mathrm{jt}+1}(+)+\mathrm{p}_{\mathrm{jt}+1}(-)-\left(\mathrm{p}_{\mathrm{jt} 1}(+)-\mathrm{p}_{\mathrm{jt}+1}(-)\right)^{2}\right]$

The answers to the questions above allow us to approximate this variance. We estimate $\mathrm{p}_{\mathrm{jt}}(+)$ and $\mathrm{p}_{\mathrm{jt}}(-)$ by the fraction of the answers $(\mathrm{A})\left(\%_{\mathrm{up} \_\mathrm{j} t}\right)$ and $(\mathrm{C})\left(\%_{\mathrm{down} \_\mathrm{j}}\right)$. We use the variance of the signal as our proxy of the variance of the demand shock. The measure of demand uncertainty is then $\left[\left(\%_{\text {up _jt }}+\%_{\text {down_jt }}\right)-\left(\%_{\text {up_jt }}-\%_{\text {down_jt }}\right)^{2}\right]$. Using this measure, we do not take into account idiosyncratic differences in uncertainty across firms of the same industry, i.e. we neglect the term $\operatorname{var}\left(\mathrm{I}_{\mathrm{ijt} t 1}\right)$. This will understate true uncertainty. However, insofar as the variance of the idiosyncratic part of the demand shock. $\operatorname{var}\left(\mathrm{I}_{\mathrm{ijt}+1}\right)$ varies little over time, it can be subsumed by entering fixed effects in the regressions. Also, our uncertainty measure does not capture changes (over time and across industries) in the "magnitude" of the demand shocks i.e. changes of $m_{j t+1}^{2}$. Entering time dummies in the regression will capture common changes in the magnitude of the demand shocks across firms. The construction of the measure also assumes that positive and negative shocks are of equal magnitude $m_{j t+l}$. We do take into account shifts, over time and across industry, in the probabilities of getting positive, zero, or negative shocks.

Our uncertainty measure is identical to Theil (1952) 's disconformity index for qualitative surveys, i.e.: $a^{2}$. $\left[\left(\%_{\text {up_jt }}+\%_{\text {down_jit }}\right)-\left(\%_{\text {up_jt }} \%_{\text {down_jit }}\right)^{2}\right]$, with $a$ set to unity. Other measures of the variance of expectations have been proposed (see Nardo, 2003, for a survey). Carlson and Parkin (1975) 's 
probability method and the time-varying parameter extension of it, are based on the assumption that agents' expectations are drawn from a common probability distribution. One of the drawbacks of these methods is that the variance of expectations cannot be computed as soon as the percentage of respondents that expect an increase, or the percentage of respondents that expect a decrease, is zero. Another method, Pesaran 's regression method $(1984,1987)$, is based on a regression of agents' expectations as to realized values. In the case of demand expectations, using such approach would impose assumptions on the regression used and identifying assumptions to evaluate realized firm 's demand. For all these reasons, we prefer to use Theil 's disconformity measure of uncertainty.

Essentially our uncertainty measure will be higher as more firms disagree about future economic conditions, or if firms change their mind very often during the same year. Our disconformity measure is a qualitative counterpart to disagreement measures. These have been shown to reflect variance changes directly. Using an inflation survey in which respondents report their forecasts together with some probability distribution, Bomberger (1996) and Giordani and Söderlind (2003) show that disagreement, i.e. the cross-sectional variance of forecasts, is proportional to individual uncertainty, i.e. the average of each individual's standard deviation of forecast errors.

Our measure of uncertainty are at the same time forward-looking and time-varying and are therefore well suited to the analysis of the microeconomic behavior of investment in a changing and uncertain environment. An additional advantage is that they are derived from directly observable firms' subjective expectations rather than being based on an assumption about the firms' expectations-formation model. To measure uncertainty the econometrician will in general face two measurement problems. First he has to postulate some forecasting model in order to estimate expectations. Second, he has to identify the appropriate variable of interest. In particular, to measure demand uncertainty, identifying restrictions are necessary to evaluate demand shocks. Price uncertainty is generally measured at the industry level because information on firm-specific output prices is seldom available. Our measures avoid both problems, as it relies on observed expectations for firm-specific demand and price changes. A possible limitation of our uncertainty measure is the short-time horizon (three months) of the question from which it is derived. However, as long as uncertainty over longer horizons is positively correlated with uncertainty over a shorter horizon, our measure will capture relevant features of firms' uncertainty.

Our measure of price uncertainty follows that of demand uncertainty; it is based on the answers to the following question of the Business Survey:

Do you expect the price of your product, in the next three months, (A) to rise, (B) to remain unchanged, $(C)$ to decrease? 
We construct our measure of price uncertainty in the same way as above, i.e. $\hat{\sigma}^{\mathrm{P}} \mathrm{jt}_{\mathrm{t}}=\left[\left(\%_{\text {up_jt }}+\%_{\text {down_jt }}\right)-\left(\%_{\text {up_jt }} \%_{\text {down_jt }}\right)^{2}\right]$. It should be clear from the outset that the answer to the question above contains entirely different information for perfectly competitive (price-taking) firms and for imperfectly competitive (price-setting) firms. For perfectly competitive firms the "price of your product" is set by market forces independently of the firm's actions. In other words, for perfectly competitive firms, the question can be interpreted as "Do you expect your (flat) demand curve to rise, to remain unchanged or to decrease?". In this case, our price uncertainty measure is a proxy for uncertainty as defined in Hartman (1972) and Abel (1983). On the contrary, for an imperfectly competitive firm, the answer to this question may be related to demand shocks as well as to supply shocks. In addition, and maybe more importantly, the answer to the question above also reflects the firm's (known) price-setting strategy rather than price uncertainty. Therefore, if our measure of price uncertainty mainly reflects intended (and known) price changes rather than market price uncertainty, it may have no effect on the level of investment. We are convinced that our measure of price uncertainty is only a correct measure if firms are price-takers. Since we have no prior knowledge on whether the firms in our sample are price-takers or not, we consider both demand and price uncertainty.

\section{The data set}

We combine three data sources to construct our data set: the Investment Survey data base, the Annual Accounts data base, and the Business Cycle Survey data base. All those three data bases are kept at the National Bank of Belgium (NBB).

We focus on large manufacturing firms. We construct two samples, one for investment plans and the other for investment realizations. After matching the various data bases and trimming for outliers, our samples contain respectively 977 observations for 114 firms for the investment plans sample and 1154 observations for 130 firms observations for the realizations sample. The period covered is 1987-2000 for the investment plans sample and 1987-1999 for the realizations sample. Focusing on large firms offers two advantages. First we avoid the aggregation bias that may result when pooling small and large firms. ${ }^{9}$ Second, because large firms in Belgium are required to provide more detailed annual accounts information, we are able to measure the capital stock and output variables more precisely. In particular, for the capital stock, we make a distinction between five types of capital goods, use depreciation rates specific to each type and evaluate the age of the capital stock separately for each component. Appendix A outlines our sample, the construction of the variables, and our trimming procedure in more detail.

The Investment Survey data base contains quantitative information on planned and realized investment. Every year, in Autumn, firms announce the amount of their planned investment for the

9 See Butzen et al (2002) for different cash flow sensitivities between small and large Belgian firms and Ghosal and Loungani (2000) for different investment-uncertainty sensitivity of US firms. 
coming year, $\mathrm{I}_{\mathrm{t}+1}^{\mathrm{P}}$, the estimated investment of the current year, $\mathrm{I}_{\mathrm{t}}$, and the realized investment in the preceding year. ${ }^{10}$ The Annual Accounts information is used to construct the capital stock, $\mathrm{K}_{\mathrm{t}}$, sales, $\mathrm{Y}_{\mathrm{t}}$, cash flow, $\mathrm{CF}_{\mathrm{t}}$, and the capital-output ratio.

Table 1 below summarizes the variables in our sample. The planned investment rate has a mean of 0.09 and a standard deviation of 0.07 . Realized investment rate is close to the planned investment with a mean of 0.08 and a standard deviation of 0.07 . It is interesting to note that price uncertainty is lower than demand uncertainty and this holds over all years and across the sectors. In most sectors, aggregate demand uncertainty peaked in the first half of the nineties and is negatively correlated with the business cycle, suggesting that firms are more uncertain about the future in downturns (see Figure 1 in Appendix).

Table 1: Descriptive statistics

\begin{tabular}{|c|c|c|c|c|c|c|c|c|c|c|}
\hline & \multicolumn{5}{|c|}{ Investment plans $I_{t+1}^{P}$} & \multicolumn{5}{|c|}{ Investment realizations $\mathbf{I}_{t+1}$} \\
\hline & mean & Std & $\min$ & median & $\max$ & mean & std & $\min$ & median & $\max$ \\
\hline $\mathrm{I}_{\mathrm{t}+1}^{\mathrm{P}} / \mathrm{K}_{\mathrm{t}}$ or $\mathrm{I}_{\mathrm{t}+1} / \mathrm{K}_{\mathrm{t}}$ & 0,09 & 0,07 & 0,00 & 0,07 & 0,51 & 0,08 & 0,07 & 0,00 & 0,06 & 0,58 \\
\hline $\mathrm{I}_{\mathrm{t}} / \mathrm{K}_{\mathrm{t}-1}$ & 0,09 & 0,09 & 0,00 & 0,07 & 0,76 & 0,09 & 0,09 & 0,00 & 0,07 & 0,95 \\
\hline$\Delta \mathrm{y}_{\mathrm{t}}$ & 0,01 & 0,17 & $-1,02$ & 0,01 & 0,73 & 0,00 & 0,16 & $-1,02$ & 0,00 & 0,73 \\
\hline$\Delta \mathrm{y}_{\mathrm{t}+1}$ & 0,01 & 0,17 & $-1,02$ & 0,01 & 0,73 & 0,00 & 0,17 & $-1,02$ & 0,00 & 0,73 \\
\hline $\mathrm{CF}_{\mathrm{t}} / \mathrm{K}_{\mathrm{t}-1}$ & 0,16 & 0,19 & $-0,48$ & 0,13 & 2,07 & 0,15 & 0,15 & $-0,48$ & 0,13 & 2,06 \\
\hline $\mathrm{y}_{\mathrm{t}-1}-\mathrm{k}_{\mathrm{t}-1}$ & 0,71 & 0,71 & $-1,56$ & 0,68 & 2,68 & 0,71 & 0,68 & $-1,24$ & 0,68 & 3,17 \\
\hline$\sigma_{s t}^{\mathrm{d}}$ & 0,35 & 0,06 & 0,18 & 0,34 & 0,54 & 0,35 & 0,06 & 0,18 & 0,34 & 0,54 \\
\hline$\sigma_{s t}^{p}$ & 0,25 & 0,05 & 0,04 & 0,25 & 0,46 & 0,25 & 0,06 & 0,04 & 0,25 & 0,46 \\
\hline
\end{tabular}

Plans sample: 977 observations and 114 firms over the period 1987-2000

Realizations sample: 1154 observations and 130 firms over the period 1987-1999

$I_{t}$ represents real fixed investment, $I_{t+1}^{P}$ plans for real fixed investment in $t+1, K_{t}$ is the capital stock at the end of period $t$, and $k_{t}$ is the $\log$ of $\mathrm{K}_{t}, \mathrm{y}_{\mathrm{t}}$ represents the $\log$ of sales in year $\mathrm{t}, \mathrm{CF}_{\mathrm{t}}$ stands for cash flow, $\sigma^{\mathrm{d}}$ for demand uncertainty and $\sigma^{\mathrm{P}}$ for price uncertainty.

\section{The empirical framework}

The literature on the theoretical framework of the investment under uncertainty generally does not offer estimable closed-form solutions for investment. The investment equations are therefore not directly suited for empirical testing. Bloom et al (2003), Ghosal and Loungani (1996, 2000), Guiso and Parigi (1999) and Leahy and Whited (1996) all use some type of reduced-form investment model. We follow this empirical literature. To capture general investment dynamics owing to adjustment costs, installation lags, realization lags etc., we specify investment as an error-

10 We very much rely on this survey because in $85 \%$ of the cases reported realized investment in the survey coincides with investment as reported in the annual accounts. Further, the average investment rate from our sample follows a similar time series pattern as the aggregate macroeconomic series of the investment-GDP ratio. 
correction model. Defining the planned investment rate in period $t$ for period $t+1$ as $\mathrm{I}_{i t+1}^{\mathrm{P}} / \mathrm{K}_{\mathrm{it}}$ and the realized investment rate as $\mathrm{I}_{\mathrm{it}+1} / \mathrm{K}_{\mathrm{it}}$, our basic specifications for planned and realized investment are

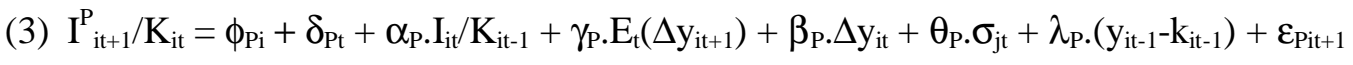

(4) $\mathrm{I}_{\mathrm{it}+1} / \mathrm{K}_{\mathrm{it}}=\phi_{\mathrm{i}}+\delta_{\mathrm{t}}+\alpha \cdot \mathrm{I}_{\mathrm{it}} / \mathrm{K}_{\mathrm{it}-1}+\gamma \cdot \Delta \mathrm{y}_{\mathrm{it}+1}+\beta \cdot \Delta \mathrm{y}_{\mathrm{it}}+\theta \cdot \sigma_{\mathrm{jt}}+\lambda \cdot\left(\mathrm{y}_{\mathrm{it}-1}-\mathrm{k}_{\mathrm{it}-1}\right)+\varepsilon_{\mathrm{it}+1}$

with $\sigma_{\mathrm{jt}}$ representing demand or output price uncertainty (the subscript $\mathrm{j}$ denoting that we compute uncertainty of price and demand shocks industry by industry, as explained in section III). Small cases represent logs. Our specification essentially follows Bond et al (2003) by modelling investment in a dynamic adjustment model. Current output is controlled by entering sales growth $\left(\Delta \mathrm{y}_{\mathrm{it}}\right)$ in the regression. We also include an error-correction term and assume, as in Bloom et al (2003), that, in the long run, the capital-output ratio is constant, so that deviations from the longrun equilibrium can be reduced to $\left(\mathrm{k}_{\mathrm{it}-1^{-}}-\mathrm{y}_{\mathrm{it}-1}\right)$. This assumption holds under constant returns to scale. When making plans in year $t$ for investments in year $t+1$, firms must forecast sales growth. Since no quantitative measure of firms' own expectations about future sales growth is available, we replace the expected sales growth in period $\mathrm{t}+1$ by realized sales growth $\Delta \mathrm{y}_{\mathrm{it}+1}$ and instrument this by lagged values of all RHS variables. This is equivalent to assuming that firms form rational expectations with respect to next-year sales growth ${ }^{11}$. Finally, we include time dummies and fixed effects in the equation. The time dummies $\left(\delta_{\mathrm{Pt}}, \delta_{\mathrm{t}}\right)$ capture macroeconomic fluctuations; and together with fixed effects they are also used as a proxy for the user cost of capital. In addition, fixed effects may account for other firm-specific factors such as productivity growth. As argued above, time dummies and fixed effects will also capture time-invariant differences across firms in the level of uncertainty and aggregate fluctuations in uncertainty. Note that, in order to take into account the possibility of financial constraints, we also experiment with including the cash flowcapital ratio $\mathrm{CF}_{\mathrm{it}} / \mathrm{K}_{\mathrm{it}-1 .}$, in the spirit of Fazzari et al (1988).

We estimate equations (3) and (4), using the system-GMM estimator, as in Arellano and Bover (1995) and Blundell and Bond (1998). This simultaneously estimates the equation in level and in first differences. In a sample only slightly larger than ours (140 firms with 7 to 9 annual observations), Blundell and Bond (1998) show that the standard first-differenced GMM estimator shows small sample biases and imprecision in the estimates which can be substantially reduced by exploiting the additional moment conditions of the system-GMM estimator. Differences of the RHS variables serve as instruments for the equation in levels, and lagged levels are used as instruments for the equation in first differences. We assume the uncertainty variables to be exogenous and therefore instrument them by themselves. We assume that all variables in period $t$

11 Replacing expected future sales growth by its realization introduces a forecast error in the residual of the investment equation. Therefore the equation must be estimated by instrumental variables. This is equivalent to using as forecast of $\Delta \mathrm{y}_{\mathrm{t}+1}$ the estimates provided by a forecasting regression on the instruments. We use the past values of all RHS variables as instruments. So it is equivalent to rational expectations where the information set consists in the past values of all RHS variables. 
are predetermined, i.e. the firm knows the realizations of the current period when it draws up its plans for the next year. Therefore, RHS variables in $\mathrm{t}-1$ and earlier are valid instruments for the difference equation and differences of the variables in $\mathrm{t}$ are additional instruments for the level equation. For the difference equation, we use the instruments $\mathrm{I}_{\mathrm{t}-1} / \mathrm{K}_{\mathrm{t}-2}$ and $\mathrm{I}_{\mathrm{t}-2} / \mathrm{K}_{\mathrm{t}-3}$. For the level equation, we use $\Delta \mathrm{I}_{\mathrm{t}} / \mathrm{K}_{\mathrm{t}-1}, \Delta \Delta \mathrm{y}_{\mathrm{t}}, \Delta\left(\mathrm{y}_{\mathrm{t}-1-1}-\mathrm{k}_{\mathrm{t}-1}\right)$, and $\sigma_{\mathrm{jt}}$ as instruments. By not taking all possible further lags we reduce the number of instruments and thereby avoid potential overfitting problems. We report the second step estimation results with t-statistics corrected for small sample bias, using Windmeijer's correction (2000).

\section{Empirical results}

We first estimate equations (3) and (4), using the system-GMM estimator, including our measure of either demand or price uncertainty. The results are shown in Table 2 for planned and realized investment. The model is correctly specified, as indicated by the standard Sargan test, $\mathrm{m} 1$ and $\mathrm{m} 2$ statistics. $^{12}$

Our results indicate that planned investment is significant and positively related to the current investment rate, consistent with a dynamic adjustment of the capital stock. Current sales growth is significant and positively related to planned investment. Next year's sales growth is also significant. The error-correction term has the right sign but is not significant at traditional levels, although it is significant at the $10 \%$ level. Demand uncertainty is statistically significant and negative. This is consistent with Caballero 's theoretical results (1991) on investment under uncertainty for imperfectly competitive firms. The point estimate is -0.120 . A one standard deviation increase in demand uncertainty (0.06) decreases the planned investment-capital ratio by 0.007 . With respect to the average level of the investment-capital ratio of 0.09 , this signifies a drop in investment of around $8.4 \%$. This represents almost one half of the cumulative effect of a one standard deviation decrease in sales growth, and one half of the effect of a one standard deviation increase in the error correction term $\mathrm{k}_{\mathrm{t}-1}-\mathrm{y}_{\mathrm{t}-1}$. Price uncertainty is insignificant. The results are robust to entering the cash flow-capital ratio (not shown in the table). The cash flow-capital ratio is never significant and the other coefficients hardly change. A non significant cash flow-capital ratio on a Belgian panel was also obtained by Bond et al. (2003) and Butzen et al (2003). ${ }^{13}$

12 The Sargan overidentifying test is a test on the identifying moment restrictions, and so tests the validity of the instrument set. The statistic $\mathrm{m} 1$ tests for first-order serial correlation in the residuals of the difference equation. These should be first-order serially correlated otherwise the level equation is misspecified. The statistic $\mathrm{m} 2$ tests for second-order serial correlation in the residuals of the difference equation. It should be insignificant, otherwise the dynamics of the level equation is misspecified. The number of observations in Table 2 is lower than that reported in Table 1 because for each firm two years are lost, in order to compute the $\mathrm{m} 1$ and $\mathrm{m} 2$ statistics.

13 We also experimented with interacting uncertainty with proxies for irreversibility and market power, since these should influence the investment-uncertainty relationship. As proxy for irreversibility we used the fraction of building in investment and we measure the markup by profits over sales. We did not find any effect of irreversibility or market power. This may be attributed to the fact that the proxies we used were poor measures of irreversibility and market power or to the fact that our sample is not heterogeneous or large enough. 
The conclusions and order of magnitude of the coefficients are similar for realized investment. The error-correction term is again only significant at the $10 \%$ level. As to investment plans, demand uncertainty is negative and significant. The effect of a one standard deviation increase in demand uncertainty on realized investment is of the same order of magnitude as for investment plans.

Our results indicate that demand uncertainty reduces both investment plans and investment realizations. We estimate the effect of a one standard increase in uncertainty to around $8.5 \%$ of -the investment ratio. This is close to but somewhat higher than what can be computed from the results of Butzen et al (2003), 2.9\%, and Guiso and Parigi (1999), 4.7\% for demand uncertainty. For sales uncertainty, von Kalckreuth (2003) estimates this effect at 3.7\%. And for price uncertainty the results in Ghosal and Loungani (1996) for competitive industries amount to $4.2 \%$ to $6.9 \%$ and in Henley et al. (2003) to $3.6 \%$.

Table 2: Effect of demand and price uncertainty on planned and realized investment

\begin{tabular}{|c|c|c|c|c|c|c|c|c|c|c|c|c|}
\hline \multirow{2}{*}{$\begin{array}{l}\text { Dependent } \\
\text { variable }\end{array}$} & \multicolumn{6}{|c|}{ Investment plans $\mathrm{I}_{\mathrm{t}+1}^{\mathrm{P}} / \mathrm{K}_{\mathrm{t}}$} & \multicolumn{6}{|c|}{ Realized investment $\mathrm{I}_{\mathrm{t}+1} / \mathrm{K}_{\mathrm{t}}$} \\
\hline & $\operatorname{coef}^{(i)}$ & t-stat ${ }^{(i i)}$ & & $\operatorname{coef}^{(i)}$ & t-stat ${ }^{(i i)}$ & & $\operatorname{coef}^{(\mathrm{i})}$ & t-stat ${ }^{(i i)}$ & & $\operatorname{coef}^{(i)}$ & t-stat ${ }^{(i i)}$ & \\
\hline constant & 0.104 & 4.491 & $* * *$ & 0.062 & 2.952 & $* * *$ & 0.101 & 4.802 & $* * *$ & 0.044 & 1.782 & $*$ \\
\hline $\mathrm{I}_{\mathrm{t}} / \mathrm{K}_{\mathrm{t}-1}$ & 0.167 & 2.289 & $* *$ & 0.196 & 2.922 & $* * *$ & 0.167 & 2.692 & $* * *$ & 0.158 & 2.466 & $* * *$ \\
\hline$\Delta \mathrm{y}_{\mathrm{t}+1}$ & 0.075 & 2.550 & $* *$ & 0.061 & 1.974 & $* *$ & 0.077 & 2511 & $* * *$ & 0.058 & 2.066 & $* *$ \\
\hline$\Delta \mathrm{y}_{\mathrm{t}}$ & 0.050 & 3.802 & $* * *$ & 0.040 & 3.073 & $* * *$ & 0.037 & 3.287 & $* * *$ & 0.035 & 2.856 & $* * *$ \\
\hline$\left(\mathrm{y}_{\mathrm{t}-1}-\mathrm{k}_{\mathrm{t}-1}\right)$ & 0.022 & 1.843 & $*$ & 0.013 & 1.336 & & 0.019 & 1.699 & $*$ & 0.009 & 0.876 & \\
\hline$\sigma_{t}^{d}$ & -0.126 & -2.464 & $* *$ & & & & -0.120 & -2.368 & $* *$ & & & \\
\hline \multirow[t]{2}{*}{$\sigma_{t}^{p}$} & & & & 0.023 & 0.449 & & & & & 0.080 & 1.124 & \\
\hline & & $\mathrm{p}$-value & & & $\mathrm{p}$-value & & & $\mathrm{p}$-value & & & $\mathrm{p}$-value & \\
\hline Sargan ${ }^{\text {(iii) }}$ & 68.305 & 0.467 & & 65.118 & 0.577 & & 60.401 & 0.534 & & 66.561 & 0.323 & \\
\hline $\mathrm{m} 1$ & -3.755 & 0.000 & & -3.568 & 0.000 & & -5.077 & 0.000 & & -4.909 & 0.000 & \\
\hline $\mathrm{m} 2$ & 1.417 & 0.157 & & 1.459 & 0.144 & & 0.963 & 0.336 & & 0.636 & 0.525 & \\
\hline \# obs \# firms & 635 & 114 & & 635 & 114 & & 764 & 130 & & 764 & 130 & \\
\hline
\end{tabular}

(i) Second-step system GMM estimates, (ii) Windmeijer's corrected t-stat (2002), (iii) second-step Sargan.

All estimations include time dummies. As to the difference equation, we use the Arellano-Bond instrument matrix for $\mathrm{I}_{\mathrm{t}-1} / \mathrm{K}_{\mathrm{t}-2}$ and $\mathrm{I}_{\mathrm{t}-2} / \mathrm{K}_{\mathrm{t}-3}$. As to the level equation, we use the Arellano-Bond instrument matrix for $\Delta \mathrm{I}_{\mathrm{t}} / \mathrm{K}_{\mathrm{t}-1}, \Delta \Delta \mathrm{Y}_{\mathrm{t}}, \Delta\left(\mathrm{y}_{\mathrm{t}-1}-\mathrm{k}_{\mathrm{t}-1}\right)$, and $\sigma_{\mathrm{t}}$

* significant at the $10 \%$ level; ** significant at the $5 \%$ level; *** significant at the $1 \%$ level

The magnitude of the coefficients is of the same order for planned and realized investment. Table 3 below reports a test for the hypothesis of equal coefficients in the planned and realized investment equations. We regress investment revisions, defined as the realized investment ratio minus planned investment ratio, on all RHS variables. If the hypothesis holds, all coefficients should be not significantly different from zero. Fixed effects should be identical in both planned and realized 
equations, so that they drop out of the investment revisions equation. This can therefore be estimated by OLS in level. ${ }^{14}$ Differences in fixed effects of the planned and realized investment equation would imply that expectations of future investment (investment plans) show a systematic bias. ${ }^{15}$ As a robustness check, we also report the system GMM estimates that allows for this possibility. Results suggest that all coefficients are equal. One possible exception is the coefficient on future sales growth, which is only significant at the $10 \%$ level in the OLS regression. The reason may be that $\Delta \mathrm{y}_{\mathrm{t}+1}$ is the only variable that is not known with certainty at the time investment plans are made, while when investment is realized, at time $t+1, \Delta y_{t+1}$ is now observed by the firm.

Table 3: Test of equal coefficients in the planned and realized investment equations

\begin{tabular}{|c|c|c|c|c|c|}
\hline & \multicolumn{3}{|c|}{ Least Squares } & \multicolumn{2}{|c|}{ System GMM } \\
\hline & $\operatorname{coef}^{(i)}$ & t-stat ${ }^{(i i)}$ & & coef & t-stat \\
\hline constant & -0.004 & -0.224 & & 0.006 & 0.255 \\
\hline $\mathrm{I}_{\mathrm{t}} / \mathrm{K}_{\mathrm{t}-1}$ & 0.044 & 1.201 & & 0.006 & 0.062 \\
\hline$\Delta \mathrm{y}_{\mathrm{t}+1}$ & 0.023 & 1.635 & $*$ & 0.020 & 1.258 \\
\hline$\Delta \mathrm{y}_{\mathrm{t}}$ & 0.002 & 0.102 & & 0.012 & 0.656 \\
\hline$\left(\mathrm{y}_{\mathrm{t}-1}-\mathrm{k}_{\mathrm{t}-1}\right)$ & -0.005 & -1.316 & & -0.010 & -0.508 \\
\hline \multirow[t]{2}{*}{$\sigma_{\text {st }}^{\mathrm{d}}$} & 0.021 & 0.486 & & 0.023 & 0.460 \\
\hline & & & & & p-value \\
\hline $\mathrm{R}^{2}$ & 0.026 & & & & \\
\hline Sargan ${ }^{(i i i)}$ & & & & 72.433 & 0.464 \\
\hline $\mathrm{m} 1$ & & & & -2.384 & 0.017 \\
\hline $\mathrm{m} 2$ & & & & 0.332 & 0.740 \\
\hline
\end{tabular}

(i) The system GMM reports second-step estimates, (ii) Windmeijer (2000) 's corrected t-stat, (iii) and second-step Sargan. All estimations include time dummies. The estimation covers the period 1989-1998.

The sample contains 622 observations for 94 firms. In system GMM, the difference equation is instrumented with $\mathrm{I}_{\mathrm{t}-1} / \mathrm{K}_{\mathrm{t}-2}, \mathrm{I}_{\mathrm{t}-2} / \mathrm{K}_{\mathrm{t}-3}, \Delta \mathrm{Y}_{\mathrm{t}}$ and $\Delta \mathrm{Y}_{\mathrm{t}-1}$. The level equation is instrumented with $\Delta \mathrm{I}_{\mathrm{t}} / \mathrm{K}_{\mathrm{t}-1}, \Delta \Delta \mathrm{Y}_{\mathrm{t}}, \Delta\left(\mathrm{y}_{\mathrm{t}-1}-\mathrm{k}_{\mathrm{t}-1}\right)$, and $\sigma_{\mathrm{t} .}$

* significant at the $10 \%$ level; ** significant at the $5 \%$ level; *** significant at the $1 \%$ level To summarize, our results indicate that investment responds negatively to changes in the level of demand uncertainty. This is consistent with the theoretical findings of Caballero (1991) for imperfectly competitive firms and irreversible capital. The effect is of a similar order for investment plans and investment realizations. The coefficients on planned and realized investment

14 First, since the equation no longer has to be differenced (to exclude the fixed effects), the endogeneity problem of lagged investment is no longer present. Second, at the time the revisions are made, in $t+1, \Delta y_{t+1}$ is known and no longer has to be instrumented.

15 This might be the case, for example, if firms report investment plans for year $t+1$ only when these have been approved by the board. So investment decided on in January $t+1$ and carried out in the same year would not be reported in the plans in year $t$. 
are equal, with the possible exception of sales growth. Indeed, if firms' investment decisions at the time of planning fully determine investment realizations, i.e. if plans made at time $t$ are simply carried out in $t+1$, the coefficients should be equal in the planned and the realized investment regressions. In such case, investment revisions should be equal to zero. If, on the contrary, firms revise their investment decisions due to new information, investment revisions may not be zero.

In this paper, we not only assess the impact of uncertainty on investment, but we also analyze the investment decision process by comparing investment plans and investment realizations. Thanks to our data set, we can construct investment revisions. Thus we are able to study another prediction made in theoretical literature, which focuses on the effect of uncertainty on the timing of the investment rather than on the level invested. The real-option theory (Dixit and Pindyck, 1994) stresses that, before undertaking investment, firms may have an incentive to wait until new information about the uncertain future is available. We now test whether firms revise their investment decision when uncertainty about the future has partly dissolved or when new information about the firm's fundamentals is available. On average in our sample investment revisions are very small. The sample mean of investment revision amounts to 0.0047, which represents $6 \%$ of the mean planned investment rate. However, there is heterogeneity in investment revisions across firms, as the standard deviation of investment revisions is equal to 0.06. Thus, although revisions are on average small, they may be substantial for some firms and years. We therefore investigate the determinants of investment revisions.

Investment plans for year $\mathrm{t}+1$ were decided on, given the information and uncertainty that existed when the decision was made (in $\mathrm{t}$ ). In year $\mathrm{t}+1$, the firm may revise its investment plans because part of the uncertainty about the future has disappeared (one year has passed since the investment decision). In our framework, at the time firms change their investment decisions they observe rather than forecast sales growth $\Delta \mathrm{y}_{\mathrm{t}+1}$. In addition, they might revise their evaluation of future uncertainty (beyond $t+1$ ), since uncertainty about period $t+1$ has now disappeared. We regress the ratio of investment revisions to capital on future sales growth, current and future uncertainty.

(5) $\left(\mathrm{I}_{\mathrm{it}+1} \mathrm{I}_{\mathrm{it}+1}^{\mathrm{P}}\right) / \mathrm{K}_{\mathrm{it}}=\alpha_{1} \cdot \Delta \mathrm{y}_{\mathrm{it}+1}+\alpha_{2} \cdot \sigma_{\mathrm{st}+1}+\alpha_{3} \cdot \sigma_{\mathrm{st}}+\varepsilon_{\mathrm{it}+1}$

Equation (5) may be viewed as a regression of investment revisions on revisions in perceived uncertainty (approximated by changes in uncertainty) if $\alpha_{3}=-\alpha_{2}$. We cannot construct revisions of future sales growth since we have no data on expected sales growth. In the investment equations expected sales growth was estimated indirectly by GMM. In equation (5) $\Delta \mathrm{y}_{\mathrm{t}+1}$ should at least be correlated with revisions in future sales growth. Therefore a significant coefficient $\alpha_{1}$ may be considered as supportive of the assumption that firms revise their investment decision due to new information regarding their fundamentals. 
Equation (5) can be estimated by OLS, provided there are no fixed effects in the investment revisions equation. If there are fixed effects, one should estimate the equation in first differences (to exclude the fixed effects). The differenced equation can be estimated by OLS because the RHS variables are predetermined. So, as a robustness check for fixed effects, we also present the OLS results on first differences.

Results, reported in Table 4, show that demand uncertainty at time $t$ and at time $t+1$ is not significant for investment revisions at time $\mathrm{t}+1$. We conclude that, as to investment, firms might find it difficult to deviate substantially from their plans, even if uncertainty changes. This suggests that the investment decision to a large extent determines investment realizations. An important factor for investment is the level of uncertainty at the time plans are on the drawing board rather than when the plans are carried out. For policymakers this implies that reducing uncertainty will only have lagged effects on investment. ${ }^{16}$

As has been set out above, we also test whether firms modify their plans in response to new information on their fundamentals, by entering sales growth in the investment revisions equation. In the equation in level, sales growth in $\mathrm{t}+1$ is significant at the $11 \%$ level only. Estimating the equation in first differences, we find that sales growth is significant at the $1 \%$ level. This suggests that firms revise their investment decisions upwards in response to demand growth. This supports the hypothesis that firms change their investment plans due to new information on their fundamentals. Indeed, $\Delta \mathrm{y}_{\mathrm{t}+1}$, was estimated by the firm at the time it made its plans, but is observed by the firm at the time the investment is realized.

Table 4: Determinants of investment revisions

\begin{tabular}{|c|c|c|c|c|c|c|c|c|c|c|c|c|}
\hline & \multicolumn{6}{|c|}{$\begin{array}{l}\text { Least Squares } \\
\text { dependent variable: } \mathrm{I}_{\mathrm{t}+1} / \mathrm{K}_{\mathrm{t}}-\mathrm{I}_{\mathrm{t}+1}^{\mathrm{P}} / \mathrm{K}_{\mathrm{t}}\end{array}$} & \multicolumn{6}{|c|}{$\begin{array}{l}\text { Least Squares on first differences } \\
\text { dependent variable: } \Delta\left(\mathrm{I}_{\mathrm{t}+1} / \mathrm{K}_{\mathrm{t}}-\mathrm{I}_{\mathrm{t}+1}^{\mathrm{P}} / \mathrm{K}_{\mathrm{t}}\right)\end{array}$} \\
\hline constant & -0.008 & -0.411 & & -0.008 & -0.412 & & 0.004 & 0.281 & & 0.002 & 0.128 & \\
\hline$\Delta \mathrm{y}_{\mathrm{t}+1}$ & 0.023 & 1.597 & + & 0.023 & 1.601 & + & 0.045 & 2.814 & $* * *$ & 0.044 & 2.794 & $* * *$ \\
\hline$\sigma_{t+1}^{\mathrm{d}}$ & 0.027 & 0.500 & & 0.029 & 0.618 & & 0.066 & 1.037 & & 0.073 & 1.094 & \\
\hline$\sigma_{t}^{\mathrm{d}}$ & 0.002 & 0.044 & & & & & -0.039 & -0.662 & & & & \\
\hline $\mathrm{R}^{2}$ & 0.021 & & & 0.021 & & & 0.052 & & & 0.051 & & \\
\hline
\end{tabular}

All estimations include time dummies; the estimation period is 1989-1998; 622 observations for 94 firms.

${ }^{+}$significant at the $11 \%$ level, * significant at the $10 \%$ level; ** significant at the $5 \%$ level; *** significant at the $1 \%$ level

16 Strictly speaking, this only applies for the uncertainty at the horizon of our measure. Realizations may differ from the plans due to shifts in longer-horizon uncertainty changes that are not captured by our measure. The same goes for longer-term sales expectations. 


\section{Conclusions}

Empirical investigations of the relationship between investment and demand uncertainty seldom use appropriate empirical proxies that are close to the concept of demand uncertainty for which the theory is developed. Using survey information in which firms reveal their forecasts regarding their own future demand and price changes has proved useful in filling this gap. Our results show that demand uncertainty reduces both planned investment and realized investment, in line with the predictions made by Caballero (1991) for imperfectly competitive firms. We find no evidence of an effect of price uncertainty on investment, which is consistent with the assumption of price-setting firms.

Our results show that demand uncertainty reduces the level of investment plans, and do so by a non-negligible amount. Butzen et al (2003), Guiso and Parigi (1999) and Patillo (1998) also report a negative effect of demand uncertainty on firms' investment. Driver et al (2002) also find that uncertainty about future business conditions reduces investment authorizations. We find that price uncertainty has no effect on investment. This contrasts with the findings of Ghosal and Loungani (1996) and Henley et al. (2003). But it confirms our earlier conjecture that firms may not be pricetakers. Indeed, if this was the case, price uncertainty would be identical to demand uncertainty, and both should be significant in our investment equations. Firms in our sample seem to be rather monopolistic firms and our measure may capture price changes that are decided on by the firm rather than uncertainty about output prices.

Finally, our results suggest that, on average, firms adjust their investment plans very little, although revisions may be substantial for some firms and years. Firms do not modify their investment decisions due to the fact that part of the uncertainty had disappeared between the time the investment was planned and the time investment is realized. This contrasts with the effect of uncertainty on the timing of investment, as stressed by the real-option theory. However, firms may revise their investment plans according to new information on their fundamentals. In particular firms may adjust their investment plans when observing (rather than predicting) sales growth, but they do so only slightly.

In sum, our results indicate that the level of uncertainty affects investment plans, but that plans are not revised as a result of a change in uncertainty. This suggests that a reduction in the level of uncertainty would indeed enhance investment, but will do so with a lagged effect, since uncertainty affects investment plans but not revisions of current investment. 


\section{Appendix}

\section{Sample description}

We construct two samples, one for investment plans, $\mathrm{I}_{t+1}^{\mathrm{P}}$, the other for realized investment, $\mathrm{I}_{\mathrm{t}+1}$. The former is used to analyze firms' investment decisions, the latter to compare our results with firms' investment realizations. We focus on large and medium-sized enterprises. This offers two advantages. First, as is often reported in the literature, small and large enterprises have a different investment behavior so that pooling the two types of firms may lead to an aggregation bias. Second, in Belgium, all firms are held to provide their annual accounts, but large firms report more detailed information. In particular, they convey information on sales and information on the capital stock by type of capital good.

Table 1 below summarizes the trimming procedure. Constructing the investment-capital ratios, the initial sample of investment plans contains 4551 observations and that of realized investment 5857 observations. We then clean our sample for outliers. Since the distribution is censored at left (investment rates are positive), trimming for outliers was carried out by taking investment rates below the 98th percentile. We trim year by year in order to avoid trimming bias due to business cycle fluctuations. By doing so, we lose about $5 \%$ of the sample. Annual accounts data of sales growth and the cash flow-capital ratio were trimmed symmetrically, by taking the P2-P98 interpercentile range year by year. Both samples were then matched together and matched with the Business Survey (to obtain uncertainty and expectation indicators) ${ }^{17}$. These samples contain all variables of the investment equation. It represents around $65 \%$ of the initial sample. Then, selecting firms with enough consecutive observations (at least five years) to estimate our ECM equation, our final samples contains 977 observations on 114 firms in the plans sample over the period 19872000 and 1154 observations on 130 firms over the period 1987-1999 in the realizations sample.

Table A.1. Trimming the sample

\begin{tabular}{lcccr}
\hline & \multicolumn{2}{c}{ Plans sample } & \multicolumn{2}{c}{ Realizations sample } \\
& \# obs & \# firms & \# obs & \# firms \\
\hline 1. investment-capital ratios & 4551 & 773 & 5857 & 851 \\
2. I/K trimmed by P98 & 4367 & 758 & 5544 & 838 \\
3. matching with trimmed CF/K, $\Delta \mathrm{y},(\mathrm{y}-\mathrm{k})$ trimmed & 2972 & 636 & 3916 & 740 \\
by P2-P98, and with the Business Survey $\left(\sigma^{\mathrm{d}}, \sigma^{\mathrm{p}}\right)$ & & & & \\
4. at least 5 consecutive observations & & & & \\
\hline
\end{tabular}

17 Since the Business Survey is conducted product by product and the Investment Survey by firm, we consider the product that accounts for the largest part of the firm 's turnover as a proxy for the firm's output. 
We focus on six manufacturing sectors: (1) food, drinks and tobacco (NACE codes 15 and 16), (2) textile, clothing, leather and shoes (NACE codes 17, 18 and 19) (3) wood, wood products and furniture (NACE codes 20), (4) paper, cardboard, publishing and printing (NACE code 21 and 22) (5) other non-metal mineral products (NACE code 26), and (6) metallurgy and metal transformation (NACE code 27 and 28). Firms are more or less evenly distributed among sectors, except for the wood sector.

Table A.2: Number of firms and observations by sector

\begin{tabular}{lllll}
\hline & \multicolumn{2}{c}{ Plans sample } & \multicolumn{2}{c}{ Realizations sample } \\
& \# firms & \# obs & \# firms & \# obs \\
\hline food, drinks and tobacco & 27 & 242 & 31 & 277 \\
textile, clothing, leader and shoes & 24 & 192 & 29 & 250 \\
wood, wood products and furniture & 5 & 39 & 6 & 52 \\
paper, cardboard, publishing and printing & 19 & 161 & 21 & 188 \\
other non-metal mineral products & 14 & 132 & 14 & 144 \\
metallurgy and metal transformation & 25 & 211 & 29 & 243 \\
Total & 114 & 977 & 130 & 1154 \\
\hline
\end{tabular}

Definition of the variables

Investment plans and investment realizations are provided in the Investment Survey. In this survey, each Autumn, firms have to provide quantitative evaluations of their investment plans for the coming year and their evaluation of investment over the current period; they are asked to report the acquisition value of total tangible fixed assets as reported in the annual accounts. To construct investment capital ratios, we construct series of the capital stock from the Annual Account data base. Sales and cash flows are also constructed from this data base. Sales are defined by turnover. Cash flow is defined as net profits plus depreciation. We use sector-specific prices to obtain real series.

For the construction of the capital stock, we distinguish between five different types of capital goods: (1) land and buildings, (2) plant and machinery, (3) furniture and motor vehicles, (4) leasing, and (5) other. For each of these capital goods and each sector we construct the capital stock in the following way.

We use the perpetual inventory method to construct the real capital stock, i.e.:

$$
\overline{\mathrm{K}_{\mathrm{t}}}=\overline{\mathrm{K}_{\mathrm{t}-1}} \cdot(1-\delta)+\mathrm{p}_{\mathrm{t}} \cdot \mathrm{I}_{\mathrm{t}} / \mathrm{p}_{\mathrm{t}}
$$

We use the industry-specific price index of investment goods provided by the National Accounts, in which the price index at 1995 is equal to one. Nominal investment is the sum of several factors, 
each of which is deflated by the investment price index of the time at which the investment was made. In particular, the acquisition of tangible assets in the current year is deflated by current prices, but sales and the disposal of old capital are deflated by the prices related to the age of this capital. ${ }^{18}$ The initial nominal capital stock at historical prices in $\mathrm{t}$ is equal to the sum of all acquisitions of new capital minus (accumulated) depreciation over the entire history of the firm up to t-1. The real initial capital stock is obtained by deflating the initial nominal capital stock with investment prices related to the age of the capital stock. ${ }^{19}$ We construct depreciation rates by sector and type of capital good, based on the lifetimes of the capital goods reported in the National Accounts.

As explained in section 3, demand (price) uncertainty is defined according to the percentage of firms within industry $\mathrm{j}$ that expect a positive demand (price) change, $\%_{\text {up_jt }}$ and the percentage of firms that expect a negative demand (price) change, $\%_{\text {down } \_\mathrm{j}}$, in the Business Cycle Survey. More

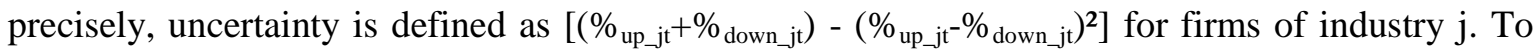
illustrate our uncertainty measures, Figure I reports demand and price uncertainty defined at the aggregate level, together with a business cycle indicator (the NBB business economic conditions index). Although there are important differences across sectors, three main features are shared by most sectors. Demand uncertainty peaked in the first half of the nineties. Price uncertainty is always lower than demand uncertainty. In macroeconomic data over the period 1987-2000 the coefficient of variation of GDP growth (0.74) was $80 \%$ higher than that of consumer price growth (0.41). Finally, both demand and price uncertainty are negatively correlated with the business cycle. This suggests that firms are more uncertain about the future in downturns than in upturns.

18 The average age of sold and used capital is estimated from the annual accounts information on depreciation. Details will be provided by the authors on request.

19 This is again inferred from annual accounts information on depreciation. 


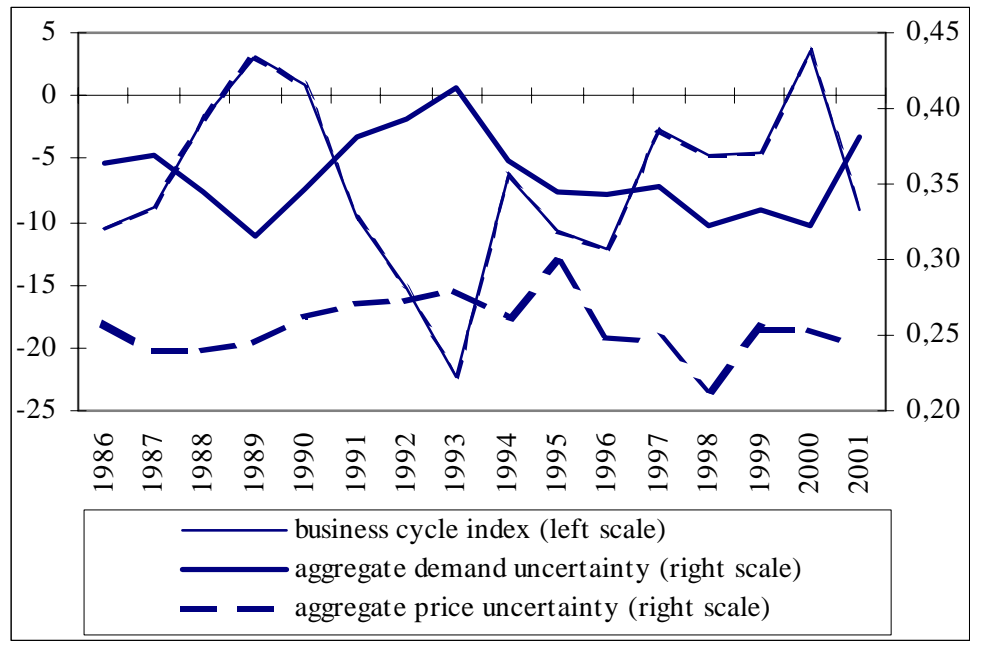

Figure I: Aggregate demand and price uncertainty and the business cycle

The business cycle index is the National Bank of Belgium business economic conditions index. Aggregate demand and price uncertainty are the Theil 's disconformity index using the answers to the National Bank of Belgium Business Survey of all firms over all industries and months of the year.

\section{References}

Abel, A. B. (1983), "Optimal investment under uncertainty", American Economic Review, 73, 228233.

Abel, A. B. and J. C. Eberly (1994), "A unified model of investment under uncertainty", American Economic Review, 84(5), 1369-1384.

Abel, A.B. and J. C. Eberly (1997), "An exact solution for the investment and value of a firm facing uncertainty, adjustment costs, and irreversibility", Journal of Economic Dynamics and Control., 21, 831-852.

Abel, A. B. and J. C. Eberly (1999), "The effect of irreversibility and uncertainty on capital accumulation", Journal of Monetary Economics, 44(3), 339-377.

Abel, A.B., A. K. Dixit, J. C. Eberly and R. S. Pindyck (1996), "Options, the value of capital and investment", Quarterly Journal of Economics., 111(3), 753-777.

Arellano, M. and O. Bover (1995), "Another look at the instrumental variable estimation of errorcomponents models", Journal of Econometrics, 68(1), 29-51.

Bloom, N., S. Bond and J. Van Reenen (2003), "Uncertainty and company investment dynamics: empirical evidence for UK firms", CEPR Discussion Paper $n^{\circ} 4025$.

Blundell, R. and S. Bond (1998), "Initial conditions and moment restrictions in dynamic panel data models", Journal of Econometrics, 87, 115-143.

Bo, H. (2002), "Idiosyncratic uncertainty and firm investment", Australian Economic Papers, 41(1), 1-14.

Bomberger (1996), "Disagreement as a measure of uncertainty", Journal of Money, Credit and Banking, 28(3), 381-392. 
Bond, S., J. Elston, J. Mairesse and B. Mulkay (2003), "Financial factors and investment in Belgium, France, Germany and the UK: a comparison using company panel data", The Review of Economics and Statistics, 85(1), 153-165.

Bulan, L. T. (2000), "Real options, irreversible investment and firm uncertainty: new evidence from US firms", mimeo.

Butzen, P., C. Fuss and Ph. Vermeulen (2002) "The interest rate and credit channels in Belgium: an investigation with micro-level firm data", Cahiers Economiques de Bruxelles - Brussels Economic Review, 45 (3), Autumn, 5-35.

Butzen, P., C. Fuss and Ph. Vermeulen (2003), "The impact of uncertainty on investment plans", in Butzen, P. and C. Fuss (eds.), Firms' Investment and Finance Decisions: Theory and Empirical Methodology, Cheltenham, UK: Edward Elgar, August 2003.

Caballero, R. (1991), "On the sign of the investment-uncertainty relationship", American Economic Review, 81, 279-288.

Carlson, J.A. and M. Parkin (1975), "Inflation expectations", Economica, 42, 123-138.

Carruth, A., A. Dickerson and A. Henley (2000), "What do we know about investment under uncertainty?", Journal of Economic Surveys, 14(2), 119-153.

Dixit, A. and R. Pindyck (1994), Investment under Uncertainty, Princeton, US: Princeton University Press.

Driver, C., K. Imai, P. Temple and G. Urga (2002), "Pooled estimators vs heterogeneous estimators: an application to the effect of uncertainty in the UK investment at the industry level", Paper presented at the 10th International Conference on Panel Data, Berlin, 5-6 July 2002.

Fazzari S., Hubbard G.R. and B.C. Petersen (1988) "Financing constraints and corporate investment", Brooking Papers on Economic Activity, 1, 141-195.

Ghosal, V. and P. Loungani (1996), "Product market competition and the impact of price uncertainty on investment: some evidence from US manufacturing industries", The Journal of Industrial Economics, 44(2), 217-228.

Ghosal, V. and P. Loungani (2000), "The differential impact of uncertainty on investment in small and large businesses", Review of Economics and Statistics, 82(2), 338-349.

Giordani, P. and P. Söderlind (2003), "Inflation forecast uncertainty", European Economic Review, 47, 1037-1059.

Guiso, L. and G. Parigi (1999), "Investment and demand uncertainty", Quarterly Journal of Economics, 114, 185-227.

Hartman R. (1972), "The effects of price and cost uncertainty on investment", Journal of economic theory, 5, 258-266.

Henley, A., A. Carruth, and A. Dickerson (2003), "Industry-wide versus firm-specific uncertainty and investment: British company panel data evidence", Economics Letters, 78(1), 87-2.

Leahy, J. V. and T. M. Whited (1996), "The effect of uncertainty on investment: some stylized facts", Journal of Money, Credit, and Banking, 28 (1), 65- 83. 
Mc Donald, R. and D. Siegel (1986), "The value of waiting to invest", Quarterly Journal of Economics, 101, 707-728.

Nardo, M. (2003), "The quantification of qualitative survey data: a critical assessment", Journal of Economic Surveys, 17 (5), 645-668.

Patillo, C. (1998), "Investment, uncertainty and irreversibility in Ghana", IMF Staff Papers, 45(3), $522-553$.

Pesaran, M.H. (1984), "Expectations formation and macroeconomic modelling", in P. Malgrange and P.A. Muet (eds), Contemporary Macroeconomic Modelling (p. 27-55), Oxford: Blackwell.

Pesaran, M.H. (1987), The limits to rational expectations, Oxford: Blackwell.

Pindyck, R.S. (1993), "A note on competitive investment under uncertainty", The American Economic Review, 83, 273-277.

Temple, P, G. Urga and C.K. Driver (2001), "The influence of uncertainty on investment in the UK: a macro or micro phenomenon?", Scottish Journal of Political Economy, 48(4), 361382.

Theil, H. (1952), "On the time shape of economic microvariables and the Munich business test", Review of the International Statistical Institute, 20, 105-120.

von Kalckreuth, U. (2003), "Exploring the role of uncertainty for corporate investment decisions in Germany", Swiss Journal of Economics and Statistics, 139 (2), 173-206.

Windmeijer, F. (2000), "A finite sample correction for the variance of linear two-step GMM estimators", Institute for Fiscal Studies, mimeo. 


\section{European Central Bank working paper series}

For a complete list of Working Papers published by the ECB, please visit the ECB's website (http://www.ecb.int).

202 "Aggregate loans to the euro area private sector" by A. Calza, M. Manrique and J. Sousa, January 2003.

203 "Myopic loss aversion, disappointment aversion and the equity premium puzzle" by D. Fielding and L. Stracca, January 2003.

204 "Asymmetric dynamics in the correlations of global equity and bond returns" by L. Cappiello, R.F. Engle and K. Sheppard, January 2003.

205 "Real exchange rate in an inter-temporal n-country-model with incomplete markets" by B. Mercereau, January 2003.

206 "Empirical estimates of reaction functions for the euro area" by D. Gerdesmeier and B. Roffia, January 2003.

207 “A comprehensive model on the euro overnight rate” by F. R. Würtz, January 2003.

208 "Do demographic changes affect risk premiums? Evidence from international data" by A. Ang and A. Maddaloni, January 2003.

209 “A framework for collateral risk control determination” by D. Cossin, Z. Huang, D. Aunon-Nerin and F. González, January 2003.

210 "Anticipated Ramsey reforms and the uniform taxation principle: the role of international financial markets" by S. Schmitt-Grohé and M. Uribe, January 2003.

211 “Self-control and savings” by P. Michel and J.P. Vidal, January 2003.

212 "Modelling the implied probability of stock market movements" by E. Glatzer and M. Scheicher, January 2003.

213 “Aggregation and euro area Phillips curves” by S. Fabiani and J. Morgan, February 2003.

214 “On the selection of forecasting models” by A. Inoue and L. Kilian, February 2003.

215 "Budget institutions and fiscal performance in Central and Eastern European countries" by H. Gleich, February 2003.

216 "The admission of accession countries to an enlarged monetary union: a tentative assessment” by M. Ca'Zorzi and R. A. De Santis, February 2003.

217 "The role of product market regulations in the process of structural change" by J. Messina, March 2003. 
218 "The zero-interest-rate bound and the role of the exchange rate for monetary policy in Japan” by G. Coenen and V. Wieland, March 2003.

219 "Extra-euro area manufacturing import prices and exchange rate pass-through" by B. Anderton, March 2003.

220 "The allocation of competencies in an international union: a positive analysis" by M. Ruta, April 2003.

221 "Estimating risk premia in money market rates" by A. Durré, S. Evjen and R. Pilegaard, April 2003.

222 "Inflation dynamics and subjective expectations in the United States" by K. Adam and M. Padula, April 2003.

223 “Optimal monetary policy with imperfect common knowledge” by K. Adam, April 2003.

224 "The rise of the yen vis-à-vis the ("synthetic") euro: is it supported by economic fundamentals?” by C. Osbat, R. Rüffer and B. Schnatz, April 2003.

225 "Productivity and the ("synthetic") euro-dollar exchange rate" by C. Osbat, F. Vijselaar and B. Schnatz, April 2003.

226 "The central banker as a risk manager: quantifying and forecasting inflation risks" by L. Kilian and S. Manganelli, April 2003.

227 “Monetary policy in a low pass-through environment” by T. Monacelli, April 2003.

228 "Monetary policy shocks - a nonfundamental look at the data" by M. Klaeffing, May 2003.

229 “How does the ECB target inflation?” by P. Surico, May 2003.

230 "The euro area financial system: structure, integration and policy initiatives" by P. Hartmann, A. Maddaloni and S. Manganelli, May 2003.

23I "Price stability and monetary policy effectiveness when nominal interest rates are bounded at zero" by G. Coenen, A. Orphanides and V. Wieland, May 2003.

232 "Describing the Fed's conduct with Taylor rules: is interest rate smoothing important?" by E. Castelnuovo, May 2003.

233 "The natural real rate of interest in the euro area" by N. Giammarioli and N. Valla, May 2003.

234 "Unemployment, hysteresis and transition" by M. León-Ledesma and P. McAdam, May 2003.

235 "Volatility of interest rates in the euro area: evidence from high frequency data" by N. Cassola and C. Morana, June 2003. 
236 "Swiss monetary targeting 1974-1996: the role of internal policy analysis" by G. Rich, June 2003.

237 "Growth expectations, capital flows and international risk sharing" by O. Castrén, M. Miller and R. Stiegert, June 2003.

238 "The impact of monetary union on trade prices" by R. Anderton, R. E. Baldwin and D. Taglioni, June 2003.

239 "Temporary shocks and unavoidable transitions to a high-unemployment regime" by W. J. Denhaan, June 2003.

240 "Monetary policy transmission in the euro area: any changes after EMU?" by I. Angeloni and M. Ehrmann, July 2003.

24I Maintaining price stability under free-floating: a fearless way out of the corner?" by C. Detken and V. Gaspar, July 2003.

242 "Public sector efficiency: an international comparison" by A. Afonso, L. Schuknecht and V. Tanzi, July 2003.

243 "Pass-through of external shocks to euro area inflation" by E. Hahn, July 2003.

244 "How does the ECB allot liquidity in its weekly main refinancing operations? A look at the empirical evidence” by S. Ejerskov, C. Martin Moss and L. Stracca, July 2003.

245 "Money and payments: a modern perspective" by C. Holthausen and C. Monnet, July 2003.

246 "Public finances and long-term growth in Europe - evidence from a panel data analysis" by D. R. de Ávila Torrijos and R. Strauch, July 2003.

247 "Forecasting euro area inflation: does aggregating forecasts by HICP component improve forecast accuracy?" by K. Hubrich, August 2003.

248 “Exchange rates and fundamentals" by C. Engel and K. D. West, August 2003.

249 "Trade advantages and specialisation dynamics in acceding countries" by A. Zaghini, August 2003.

250 "Persistence, the transmission mechanism and robust monetary policy" by I. Angeloni, G. Coenen and F. Smets, August 2003.

25 I "Consumption, habit persistence, imperfect information and the lifetime budget constraint" by A. Willman, August 2003.

252 "Interpolation and backdating with a large information set" by E. Angelini, J. Henry and M. Marcellino, August 2003.

253 "Bond market inflation expectations and longer-term trends in broad monetary growth and inflation in industrial countries, 1880-200I" by W. G. Dewald, September 2003. 
254 "Forecasting real GDP: what role for narrow money?" by C. Brand, H.-E. Reimers and F. Seitz, September 2003.

255 "Is the demand for euro area M3 stable?" by A. Bruggeman, P. Donati and A. Warne, September 2003.

256 "Information acquisition and decision making in committees: a survey" by K. Gerling, H. P. Grüner, A. Kiel and E. Schulte, September 2003.

257 “Macroeconomic modelling of monetary policy” by M. Klaeffling, September 2003.

258 "Interest rate reaction functions and the Taylor rule in the euro area" by P. GerlachKristen, September 2003.

259 "Implicit tax co-ordination under repeated policy interactions" by M. Catenaro and J.-P. Vidal, September 2003.

260 "Aggregation-theoretic monetary aggregation over the euro area, when countries are heterogeneous” by W. A. Barnett, September 2003.

261 "Why has broad money demand been more stable in the euro area than in other economies? A literature review” by A. Calza and J. Sousa, September 2003.

262 "Indeterminacy of rational expectations equilibria in sequential financial markets" by P. Donati, September 2003.

263 "Measuring contagion with a Bayesian, time-varying coefficient model" by M. Ciccarelli and A. Rebucci, September 2003.

264 "A monthly monetary model with banking intermediation for the euro area" by A. Bruggeman and M. Donnay, September 2003.

265 "New Keynesian Phillips Curves: a reassessment using euro area data" by P. McAdam and A. Willman, September 2003.

266 "Finance and growth in the EU: new evidence from the liberalisation and harmonisation of the banking industry" by D. Romero de Ávila, September 2003.

267 "Comparing economic dynamics in the EU and CEE accession countries" by R. Süppel, September 2003.

268 "The output composition puzzle: a difference in the monetary transmission mechanism in the euro area and the US" by I. Angeloni, A. K. Kashyap, B. Mojon and D. Terlizzese, September 2003.

269 "Zero lower bound: is it a problem with the euro area?" by G. Coenen, September 2003.

270 "Downward nominal wage rigidity and the long-run Phillips curve: simulation-based evidence for the euro area" by G. Coenen, September 2003.

27I “Indeterminacy and search theory” by N. Giammarioli, September 2003. 
272 "Inflation targets and the liquidity trap" by M. Klaeffling and V. López Pérez, September 2003.

273 "Definition of price stability, range and point inflation targets: the anchoring of long-term inflation expectations" by E. Castelnuovo, S. Nicoletti-Altimari and D. RodriguezPalenzuela, September 2003.

274 "Interpreting implied risk neutral densities: the role of risk premia" by P. Hördahl and D. Vestin, September 2003.

275 "Identifying the monetary transmission mechanism using structural breaks" by A. Beyer and R. Farmer, September 2003.

276 "Short-term estimates of euro area real GDP by means of monthly data" by G. Rünstler and F. Sédillot, September 2003.

277 "On the indeterminacy of determinacy and indeterminacy" by A. Beyer and R. Farmer, September 2003.

278 "Relevant economic issues concerning the optimal rate of inflation" by D. R. Palenzuela, G. Camba-Méndez and J. Á. García, September 2003.

279 "Designing targeting rules for international monetary policy cooperation" by G. Benigno and P. Benigno, October 2003.

280 “Inflation, factor substitution and growth" by R. Klump, October 2003.

28I "Identifying fiscal shocks and policy regimes in OECD countries" by G. de Arcangelis and S. Lamartina, October 2003.

282 "Optimal dynamic risk sharing when enforcement is a decision variable" by T. V. Koeppl, October 2003.

283 "US, Japan and the euro area: comparing business-cycle features" by P. McAdam, November 2003.

284 “The credibility of the monetary policy 'free lunch"' by J. Yetman, November 2003.

285 "Government deficits, wealth effects and the price level in an optimizing model" by B. Annicchiarico, November 2003.

286 "Country and sector-specific spillover effects in the euro area, the United States and Japan" by B. Kaltenhaeuser, November 2003.

287 “Consumer inflation expectations in Poland” by T. Łyziak, November 2003.

288 “Implementing optimal control cointegrated I(I) structural VAR models" by F. V. Monti, November 2003.

289 "Monetary and fiscal interactions in open economies" by G. Lombardo and A. Sutherland, November 2003. 
290 "Inflation persistence and robust monetary policy design" by G. Coenen, November 2003.

291 "Measuring the time-inconsitency of US monetary policy” by P. Surico, November 2003.

292 "Bank mergers, competition and liquidity" by E. Carletti, P. Hartmann and G. Spagnolo, November 2003.

293 "Committees and special interests" by M. Felgenhauer and H. P. Grüner, November 2003.

294 "Does the yield spread predict recessions in the euro area?" by F. Moneta, December 2003.

295 “Optimal allotment policy in the eurosystem's main refinancing operations?" by C. Ewerhart, N. Cassola, S. Ejerskov and N. Valla, December 2003.

296 "Monetary policy analysis in a small open economy using bayesian cointegrated structural VARs?" by M. Villani and A. Warne, December 2003.

297 “Measurement of contagion in banks' equity prices” by R. Gropp and G. Moerman, December 2003.

298 "The lender of last resort: a 2 I st century approach" by X. Freixas, B. M. Parigi and J.-C. Rochet, December 2003.

299 "Import prices and pricing-to-market effects in the euro area" by T. Warmedinger, January 2004.

300 "Developing statistical indicators of the integration of the euro area banking system" by M. Manna, January 2004.

301 "Inflation and relative price asymmetry” by A. Rátfai, January 2004.

302 “Deposit insurance, moral hazard and market monitoring” by R. Gropp and J. Vesala, February 2004.

303 "Fiscal policy events and interest rate swap spreads: evidence from the EU" by A. Afonso and R. Strauch, February 2004.

304 "Equilibrium unemployment, job flows and inflation dynamics" by A. Trigari, February 2004.

305 "A structural common factor approach to core inflation estimation and forecasting" by C. Morana, February 2004.

306 "A markup model of inflation for the euro area” by C. Bowdler and E. S. Jansen, February 2004.

307 "Budgetary forecasts in Europe - the track record of stability and convergence programmes" by R. Strauch, M. Hallerberg and J. von Hagen, February 2004.

308 "International risk-sharing and the transmission of productivity shocks" by G. Corsetti, L. Dedola and S. Leduc, February 2004.

309 "Monetary policy shocks in the euro area and global liquidity spillovers" by J. Sousa and A. Zaghini, February 2004.

310 "International equity flows and returns: A quantitative equilibrium approach" by R. Albuquerque, G. H. Bauer and M. Schneider, February 2004.

311 "Current account dynamics in OECD and EU acceding countries - an intertemporal approach" by M. Bussière, M. Fratzscher and G. Müller, February 2004. 
312 "Similarities and convergence in G-7 cycles" by F. Canova, M. Ciccarelli and E. Ortega, February 2004.

313 "The high-yield segment of the corporate bond market: a diffusion modelling approach for the United States, the United Kingdom and the euro area" by G. de Bondt and D. Marqués, February 2004.

314 "Exchange rate risks and asset prices in a small open economy" by A. Derviz, March 2004.

315 "Option-implied asymmetries in bond market expectations around monetary policy actions of the ECB" by S. Vähämaa, March 2004.

316 "Cooperation in international banking supervision" by C. Holthausen and T. Rønde, March 2004.

317 "Fiscal policy and inflation volatility" by P. C. Rother, March 2004.

318 "Gross job flows and institutions in Europe" by R. Gómez-Salvador, J. Messina and G. Vallanti, March 2004.

319 "Risk sharing through financial markets with endogenous enforcement of trades" by T. V. Köppl, March 2004.

320 "Institutions and service employment: a panel study for OECD countries" by J. Messina, March 2004.

321 "Frequency domain principal components estimation of fractionally cointegrated processes" by C. Morana, March 2004.

322 "Modelling inflation in the euro area" by E. S. Jansen, March 2004.

323 "On the indeterminacy of New-Keynesian economics" by A. Beyer and R. E. A. Farmer, March 2004.

324 “Fundamentals and joint currency crises" by P. Hartmann, S. Straetmans and C. G. de Vries, March 2004.

325 "What are the spill-overs from fiscal shocks in Europe? An empirical analysis" by M. Giuliodori and R. Beetsma, March 2004.

326 "The great depression and the Friedman-Schwartz hypothesis" by L. Christiano, R. Motto and M. Rostagno, March 2004.

327 "Diversification in euro area stock markets: country versus industry" by G. A. Moerman, April 2004.

328 "Non-fundamental exchange rate volatility and welfare" by R. Straub and I. Tchakarov, April 2004.

329 "On the determinants of euro area FDI to the United States: the knowledge-capital-Tobin's Q framework, by R. A. De Santis, R. Anderton and A. Hijzen, April 2004.

330 "The demand for euro area currencies: past, present and future" by B. Fischer, P. Köhler and F. Seitz, April 2004.

331 "How frequently do prices change? evidence based on the micro data underlying the Belgian CPI" by L. Aucremanne and E. Dhyne, April 2004.

332 "Stylised features of price setting behaviour in Portugal: 1992-200 I" by M. Dias, D. Dias and P. D. Neves, April 2004. 
333 "The pricing behaviour of Italian firms: New survey evidence on price stickiness" by

S. Fabiani, A. Gattulli and R. Sabbatini, April 2004.

334 "Is inflation persistence intrinsic in industrial economies?" by A. T. Levin and J. M. Piger, April 2004.

335 “Has eura-area inflation persistence changed over time?” by G. O’Reilly and K. Whelan, April 2004.

336 "The great inflation of the 1970s" by F. Collard and H. Dellas, April 2004.

337 "The decline of activist stabilization policy: Natural rate misperceptions, learning and expectations" by A. Orphanides and J. C. Williams, April 2004.

338 "The optimal degree of discretion in monetary policy" by S. Athey, A. Atkeson and P. J. Kehoe, April 2004.

339 "Understanding the effects of government spending on consumption” by J. Galí, J. D. López-Salido and J. Vallés, April 2004.

340 "Indeterminacy with inflation-forecast-based rules in a two-bloc model” by N. Batini, P.Levine and J. Pearlman, April 2004.

34I "Benefits and spillovers of greater competition in Europe: A macroeconomic assessment" by T. Bayoumi, D. Laxton and P. Pesenti, April 2004.

342 "Equal size, equal role? Interest rate interdependence between the euro area and the United States" by M. Ehrmann and M. Fratzscher, April 2004.

343 “Monetary discretion, pricing complementarity and dynamic multiple equilibria” by R. G. King and A. L. Wolman, April 2004.

344 "Ramsey monetary policy and international relative prices" by E. Faia and T. Monacelli, April 2004.

345 "Optimal monetary and fiscal policy: A linear-quadratic approach" by P. Benigno and M. Woodford, April 2004.

346 "Perpetual youth and endogenous labour supply: a problem and a possible solution" by G. Ascari and N. Rankin, April 2004.

347 'Firms' investment decisions in response to demand and price uncertainty" by C. Fuss and P. Vermeulen, April 2004. 
